\title{
Ekstrak Buah Kersen (Muntingia calabura) dalam Menurunkan Jumlah Sel Goblet pada Tikus yang Dipapar Asap Rokok
}

\author{
Ika Dyah Kurniati ${ }^{1}$, Afiana Rohmani ${ }^{2}$ \\ ${ }^{1,2}$ Fakultas Kedokteran, Universitas Muhammadiyah Semarang \\ Jl. Wonodri Sendang Raya No. 2A Semarang 50242 \\ Email: ikadyahk2705@gmail.com
}

\begin{abstract}
ABSTRAK
Asap rokok dapat meningkatkan stres oksidatif yang menyebabkan aktivasi dari Epidermal Growth Factor Receptor (EGFR) sehingga mencegah apoptosis sel bersilia serta mendiferensiasi sel bersilia menjadi sel goblet. Buah kersen (Muntingia calabura) mengandung antioksidan diantaranya flavonoid. Tujuan penelitian ini membuktikan pengaruh pemberian ekstrak buah kersen terhadap jumlah sel goblet pada trakea tikus. Penelitian ini merupakan penelitian eksperimental laboratorik dengan rancangan Post Test Only Control Group Desain. Tikus sejumlah 18 ekor dibagi 3 kelompok, kemudian di papar asap rokok 7 batang perhari dan ekstrak buah kersen (EBK) selama 4 minggu. Kelompok pertama sebagai kontrol (K) diberi plasebo, kelompok Perlakuan 1 (P1) diberi EBK $100 \mathrm{mg} / \mathrm{kgBB} / \mathrm{hari}$ dan kelompok Perlakuan 2 (P2) diberi EBK 200mg/kgBB/hari. Perbedaan jumlah sel goblet dianalisis dengan Kruskal-Wallis Test dilanjutkan Post Hoc Mann-Whitney U Test. Hasil menunjukkan bahwa rerata sel goblet pada kelompok perlakuan $1 \quad(\mathrm{P} 1=14,44)$ paling sedikit dibandingkan kelompok perlakuan $2(\mathrm{P} 2=15,32)$ dan kelompok kontrol $(\mathrm{K}=23,08)$. Ada perbedaan bermakna jumlah sel goblet antara kelompok K dengan P1 $(\rho<0.0001)$ dan kelompok P1 dengan P2 $(\rho=0,002)$, namun tidak terdapat perbedaan yang bermakna antara kelompok K dengan $\mathrm{P}(\rho=0,126)$. Simpulannya ekstrak buah kersen mampu menurunkan jumlah sel goblet trakea tikus yang di papar asap rokok.
\end{abstract}

Kata kunci: asap rokok, Muntingia calabura, sel goblet

\section{Kersen Fruit Extract (Muntingia calabura) Decreases the Number of Goblet Cells in Rats Exposed to Cigarette Smoked}

\begin{abstract}
Cigarette smoke increase oxidative stress that leads to activation of the Epidermal Growth Factor Receptor (EGFR), thus preventing ciliated cells apoptosis and differentiating ciliated cells into goblet cells. Cherry fruit (Muntingia calabura) contains antioxidants including flavonoids. The purpose of this studyis to proves the effect of cherry fruit extract on the number of goblet cells in rat trachea. This research is a laboratory experimental research with Posttest Only Control Group Design design. 18 rats were divided into 3 groups that had been exposed 7 cigarrete smoke a day and given cherry fruit extract (CFE) for 4 weeks. The first group as the control group (K) was given a placebo, treatment group 1 (T1) and treatment group 2 (T2) were treated with 100 and 200mg/kgBodyWeight/ day CFE, respectively. The difference in the number of goblet cells were analyzed with Kruskal-Wallis Test followed by Post Hoc Mann-Whitney U Test. The result showed that the mean of goblet cell in treatment group $1(\mathrm{P} 1=14,44)$ was less than treatment group $2(\mathrm{P} 2=15,32)$ and control group $(\mathrm{K}=23,08)$. There was a significant difference in the number of goblet cells between groups of $\mathrm{K}$ with P1 $(\rho<0.0001)$ and groups of P1 with P2 $(\rho=0.002)$, but there was no significant difference between groups of $\mathrm{K}$ and $\mathrm{P}(\rho=0.126)$. The conclusion is kersen fruit extract able to reduce the number of goblet cell in rat's trachea that exposed to cigarette smoked.
\end{abstract}

Keywords: cigarette smoke, Muntingia calabura, goblet cell 


\section{Pendahuluan}

Saat ini, Penyakit Paru Obstruksi Kronis (PPOK) merupakan salah satu masalah kesehatan di masyarakat, dimana prevalensinya yang tinggi serta memberikan dampak sosialekonomi yang buruk. PPOK saat ini merupakan penyebab kematian no. 4 di seluruh dunia, dan kemungkinan akan meningkat menjadi no 3 pada tahun 2020 . $^{1,2}$ PPOK dapat disebabkan antara lain oleh polusi udara dan asap rokok. ${ }^{2,3,4,5}$ Menurut WHO, Indonesia merupakan negara ketiga setelah Cina dan India yang memiliki jumlah perokok aktif terbanyak di dunia yaitu sebesar 61,4 juta perokok. Perilaku merokok penduduk Indonesia cenderung meningkat dari $34,2 \%$ pada tahun 2007 menjadi $36,3 \%$ pada tahun 2013. ${ }^{1}$

Salah satu manifestasi penyakit PPOK adalah peningkatan produksi sputum. Peningkatan produksi sputum yang berlebihan ini sebagai proses awal terjadinya hambatan aliran udara pada penderita PPOK. Pada perokok, proporsi sel bersilia terhadap sel goblet berubah, dimana proporsi sel goblet lebih tinggi daripada sel bersilia, yang sebenarnya diperlukan untuk membantu membersihkan peningkatan partikel polutan dan gas. Hal ini sesuai dengan penelitian yang dilakukan oleh Gultom yang membuktikan bahwa terdapat penambahan jumlah sel goblet pada saluran pernapasan tikus putih jantan strain Sprague Dawley yang dipapar asap rokok selama 21 hari. ${ }^{6,7}$

Dalam setiap hisapan rokok, terdapat $10^{14}$ radikal bebas dan dapat dipertahankan dalam waktu yang relatif lama (>10 menit) ${ }^{8}$ Asap rokok tersebut merupakan oksidan yang dapat menghilangkan antioksidan intraseluler dalam sel paru-paru dan berhubungan dengan mekanisme peningkatan stres oksidatif dengan mengaktifkan makrofag alveolus untuk melepaskan sitokin antara lain LB4, IL-8 dan TNF- $\alpha .{ }^{9}, 10,11,12$

Asap rokok dapat menyebabkan kerusakan alveolar dan inflamasi, yang disebabkan oleh asap rokok itu sendiri, stres oksidatif maupun kerusakan sel alveolar. ${ }^{13,14,15}$ Hiperplasia atau peningkatan jumlah sel epitel bronkhus akibat stress oksidatif yang diinduksi oleh asap rokok disebabkan oleh aktivasi dari Epidermal Growth Factor Receptor (EGFR). Reseptor ini terlibat dalam berbagai macam proses biologi termasuk diantaranya proliferasi dan diferensiasi sel. Aktivasi EFGR akan mencegah apoptosis sel bersilia dan mengirim sinyal pada IL-13 untuk mendiferensiasi sel-sel bersilia menjadi sel goblet. Selain itu, aktivasi dari EFGR akan menginduksi gen MUC5AC yang menyebabkan sintesis mukus dan hiperplasi sel goblet pada tikus secara invivo. ${ }^{16}$

Untuk mencegah dampak buruk akibat senyawa radikal penyebab kerusakan sel, dibutuhkan antioksidan yang dapat berasal dari tubuh sendiri maupun dari luar. Dari dalam tubuh akan dibentuk senyawa untuk menetralisir antara lain SOD (superoksid dismutase). Sedangkan dari luar antara lain dari makanan dimana mengandung zat antioksidan yang digunakan sebagai pemutus rantai (chain-breaking antioxidant) yaitu

Ika Dyah Kurniati dan Afiana Rohmani, Ekstrak Buah Kersen (Muntingia calabura) dalam Menurunkan Jumlah Sel Goblet pada Tikus yang Dipapar Asap Rokok 
vitamin $\mathrm{C}$, vitamin $\mathrm{E}$, beta karoten, dan golongan flavonoid. ${ }^{17,18}$ Pigmen antosianin yang dapat bertindak sebagai antioksidan. Adanya kemampuan antosianin untuk memangsa radikal bebas yang langsung berasal dari asap rokok maupun radikal bebas yang timbul akibat respon inflamasi, maka antosianin dapat menekan terjadinya peroksidasi lipid. ${ }^{19}$

Buah kersen (Muntingia calabura Linn) adalah buah yang banyak tumbuh di Indonesia, namun masyarakat belum banyak mengetahui manfaat dari buah kersen dan menyebabkan banyaknya buah kersen yang tidak digunakan manfaatkan terutama dibidang kesehatan. Buah kersen (Muntingia calabura Linn) memiliki aktivitas antioksidan yang kuat karena kandungan asam askorbat (vitamin C) yang tinggi, vitamin A dan juga mineral seperti kalsium dan fosfor. Kandungan vitamin C buah kersen $(379,75 \mathrm{mg}) 3 \mathrm{x}$ lipat dari buah mengkudu (175) mg. Dosis lethal ekstrak buah kersen adalah $1000 \mathrm{mg} / \mathrm{kg} .{ }^{20}$ Hasil ekstrak polifenol buah kersen menunjukkan bahwa buah kersen mengandung antioksidan antara lain Vitamin C (33,6 mg AAE/g ekstrak), Vitamin E (14,7 mg TE/g ekstrak), total fenol (121,1 mg GAE/g ekstrak), flavonoid (173,2 $\mathrm{mg} \mathrm{RE} / \mathrm{g}$ ekstrak) dan antosianin (82,4 mg CGE/g ekstrak). ${ }^{21}$

Buah kersen merupakan salah satu sumber antioksidan alami yang mudah dibudidayakan di Indonesia. Adanya kandungan antioksidan pada buah kersen, maka diharapkan dengan pemberian ekstrak buah kersen dapat menurunkan jumlah oksidan yang disebabkan paparan asap rokok yang terhirup oleh paru-paru, sehingga dapat menurunkan jumlah sel goblet. Tujuan penelitian ini untuk membuktikan pengaruh pemberian ekstrak buah kersen terhadap jumlah sel goblet pada trakea tikus yang dipapar asap rokok.

\section{Metode Penelitian}

Penelitian ini merupakan penelitian eksperimental laboratorik dengan rancangan Post Test Only Control Group Desain. Penelitian ini telah mendapatkan persetujuan dari komisi etik Fakultas Kedokteran Universitas Diponegoro Semarang. Tempat penelitian dilakukan di di Laboratorium Unit Pangan dan Gizi Pusat Antar Universitas (PAU) Universitas Gajah Mada (UGM), Laboratorium Patologi Anatomi FK UGM-RS Sardjito Yogyakarta dan Laboratorium Patologi Anatomi FK UNDIP Semarang periode Agustus - Oktober 2016.

\section{Subjek Penelitian}

Hewan coba yang dipakai pada penelitian ini adalah tikus putih jantan galur Sprague-Dawley. Kriteria inklusi adalah umur 2-3 bulan, berat 150-200 gram, sehat. Kriteria eklusi adalah tikus tidak bergerak aktif, terdapat abnormalitas anatomi yang tampak. Kriteria drop out adalah tikus mati. Besar sampel ditentukan berdasarkan rumus WHO (1993) jumlah sampel setiap kelompok perlakuan minimal 5 ekor tikus tiap kelompok, oleh karena terdapat 3 kelompok maka dibutuhkan 15 ekor tikus. Antisipasi drop out 
dilakukan dengan menambahkan 1 tikus pada masing-masing kelompok.

\section{Pembuatan ekstrak metanol buah kersen (Muntingia calabura)}

Buah kersen segar di blender kemudian diekstrak menggunakan metanol dengan perbandingan 1:3 (jus buah: pelarut) menggunakan orbital shaker pada suhu ruang, kemudian ekstrak di sentrifuge dan supernatan dikumpulkan. Maserat didapatkan dengan menggunakan rotary evaporator pada suhu $40^{\circ} \mathrm{C}$ dilanjutkan proses penguapan dengan nitrogen sehingga didapatkan ekstrak buah kersen yang kental dan konsentrasinya mendekati $99 \%$. Dosis ekstrak buah kersen yang dibuat adalah $100 \mathrm{mg} / \mathrm{kg}$ BB dan 200 $\mathrm{mg} / \mathrm{kg}$ yang dilarutkan dalam $\mathrm{Na}$ CMC $0,5 \%$ $2 \mathrm{ml} / 200 \mathrm{gr}$ BB.

\section{Protokol Penelitian}

Sampel tikus Sprague-Dawley jantan sebanyak 18 ekor, dibagi menjadi 3 kelompok secara random, dimana tiap kelompok terdapat 6 ekor tikus Sprague-Dawley jantan. Kelompok pertama sebagai kontrol (K) yang diberikan placebo ( $\mathrm{Na} \mathrm{CMC} \quad 0,5 \%$ ) dan paparan asap rokok kretek tanpa filter 7 batang per hari. Kelompok perlakuan satu (P1) yang diberikan ekstrak buah kersen melalui sonde lambung dengan dosis $100 \mathrm{mg} / \mathrm{kg}$ BB yang dilarutkan dalam Na CMC 0,5\% 2ml/200gr BB dan paparan asap rokok 7 batang per hari. Kelompok ketiga sebagai perlakuan dua (P2) yang diberikan ekstrak buah kersen melalui sonde lambung dengan dosis $200 \mathrm{mg} / \mathrm{kg}$ BB yang dilarutkan dalam $\mathrm{Na}$ CMC $0,5 \%$ 2ml/200gr BB dan paparan asap rokok 7 batang per hari. Pemberian ekstrak buah kersen diberikan 30 menit sebelum pemaparan asap rokok. Paparan asap rokok dan pemberian ekstrak buah kersen dilakukan selama 4 minggu.

Setelah 4 minggu perlakuan, tikus di terminasi dan diambil jaringan trakea kemudian dilakukan pemrosesan jaringan dan pengecatan HE sesuai standar pemeriksaan histopatologi di Laboratorium Patologi Anatomi FK UGM.

\section{Perhitungan Jumlah Sel Goblet}

Perhitungan jumlah sel goblet dilakukan oleh Ahli Patologi Anatomi di laboratorium Patologi Anatomi FK UGM. Sebanyak 5 (lima) lapangan pandang dari setiap preparat di hitung jumlah sel gobletnya dengan perbesaran 400x.

Data disajikan dalam bentuk tabel. Data di uji normalitas data menggunakan uji OneSample Kolmogorov-Smirnov Test. Oleh karena distribusi data tidak normal sehingga digunakan uji beda menggunakan uji statistik parametrik Kruskal-Wallis Test dilanjutkan Post Hoc Mann-Whitney U Test.

\section{Hasil}

Penelitian ini dilakukan pada 18 tikus Sprague-Dawley yang berikan paparan asap rokok, sampel dikelompokkan menjadi tiga kelompok yaitu kelompok kontrol, kelompok perlakuan pertama dan kelompok perlakuan kedua. Subyek diberikan paparan asap rokok 7 batang perhari serta pemberian ekstrak buah kersen dengan dosis 100 dan 200mg/kgBB/hari

Ika Dyah Kurniati dan Afiana Rohmani, Ekstrak Buah Kersen (Muntingia calabura) dalam Menurunkan Jumlah Sel Goblet pada Tikus yang Dipapar Asap Rokok 
selama 4 minggu. Setelah 4 minggu subyek dilakukan terminasi dan diambil jaringan trakeanya, lalu dilakukan pemrosesan jaringan untuk membuat blok parafin, kemudian dilakukan pengecatan HE.

Hasil ketiga kelompok didapatkan bahwa pada kelompok kontrol (K) 2 sampel mati pada hari ke-6, dan 2 sampel mati pada hari ke-13, sehingga sampel yang hidup sampai dengan waktu terminasi sebanyak 2 ekor. Untuk memenuhi agar data dapat diolah, untuk perhitungan jumlah sel goblet dilakukan pada kedua sampel tersisa pada lapang pandang yang berbeda. Pada kelompok perlakuan 1(P1) terdapat satu sampel yang mati pada hari ke-13, sehingga 5 sampel tersisa diambil datanya untuk dianalisis. Sedangkan pada kelompok perlakuan 2 (P2) keenam sampel hidup sampai dengan waktu terminasi.

Tabel 1. Jumlah Sel Goblet pada Kelompok Perlakuan dan Kelompok Kontrol

\begin{tabular}{ccccc}
\hline Kelompok & Mean $\pm S D$ & Median & Minimum & Maximum \\
\hline Kontrol & $23,08 \pm 11,7$ & 16 & 12 & 40 \\
Perlakuan & $14,44 \pm 14,8$ & 10 & 8 & 81 \\
1 & & & & \\
Perlakuan & $15,32 \pm 4,4$ & 16 & 8 & 26 \\
2 & & & & \\
\hline
\end{tabular}

Hasil pembacaan dan perhitungan jumlah sel goblet dilakukan oleh ahli Patologi Anatomi. Sebanyak 5 (lima) lapangan pandang dari setiap preparat di hitung jumlah sel gobletnya dengan hasil seperti pada Tabel 1.

Data tersebut menunjukkan bahwa rerata jumlah sel goblet yang terkecil yaitu pada kelompok perlakuan 1 (P1) sejumlah $(14,44 \pm$ 14,8) sedangkan yang terbanyak yaitu pada kelompok kontrol (K) sejumlah $(23,08 \pm 11,7)$. Hasil uji normalitas data terhadap variabel penelitian dengan One-Sample KolmogorovSmirnov Test menunjukkan bernilai $P<0,05$, atau berbeda bermakna, yang berarti bahwa data variabel-variabel penelitian tersebut tidak terdistribusi normal sehingga dilakukan analisis statistik Kruskal-Wallis Test.
Hasil analisis statistik dengan KruskalWallis Test didapatkan bahwa ada perbedaan antar kelompok secara statistik dengan nilai $\rho<0.0001$. Untuk mengetahui perbedaan tiap - tiap kelompok dilanjutkan dengan analisis Mann-Whitney $U$ Test dengan hasil ada perbedaan yang bermakna $(\rho<0.0001)$ jumlah sel goblet antara kelompok kontrol dengan perlakuan 1 (kelompok ekstrak buah kersen $100 \mathrm{mg} / \mathrm{kg} \mathrm{BB} /$ hari) dan kelompok perlakuan 1 dengan perlakuan 2 (kelompok ekstrak buah kersen $100 \mathrm{mg} / \mathrm{kg}$ BB/hari dan kelompok ekstrak buah kersen $200 \mathrm{mg} / \mathrm{kg} \mathrm{BB} / \mathrm{hari}) \rho=$ 0,002 , namun, tidak terdapat perbedaan yang bermakna antara kelompok kontrol dengan perlakuan $2(\rho=0,126)$. Hal ini menunjukkan bahwa tidak terdapat perbedaaan yang 
bermakna jumlah sel goblet pada kelompok yang tidak diberikan ekstrak buah kersen dengan kelompok yang diberikan ekstrak buah kersen dosis $200 \mathrm{mg} / \mathrm{kgBB} / \mathrm{hari}$.

Tabel 2. Perbedaan Jumlah Sel Goblet antara kelompok perlakuan dan kelompok kontrol $(\mathrm{N}=75)$ dengan Kruskal-Wallis Test dan Mann-Whitney U Test

\begin{tabular}{ccccc}
\hline \multirow{2}{*}{ Kelompok } & \multicolumn{3}{c}{ Mann-Whitney U Test } & $\begin{array}{c}\text { Kruskal- } \\
\text { Wallis Test }\end{array}$ \\
\cline { 2 - 5 } & Kontrol & Perlakuan 1 & Perlakuan 2 & \\
\hline Kontrol & - & $\boldsymbol{\rho}<\mathbf{0 . 0 0 0 1 *}$ & $\boldsymbol{P}=\mathbf{0 , 1 2 6}$ & \\
\hline Perlakuan 1 & $\boldsymbol{\rho}<\mathbf{0 . 0 0 0 1 *}$ & - & $\boldsymbol{\rho}=\mathbf{0 , 0 0 2 *}$ & $<\mathbf{0 . 0 0 0 1 *}$ \\
\hline Perlakuan 2 & $\boldsymbol{P}=\mathbf{0 , 1 2 6}$ & $\boldsymbol{\rho}=\mathbf{0 , 0 0 2 *}$ & - & \\
\hline$* p<0,05$ (signifikan) & & &
\end{tabular}

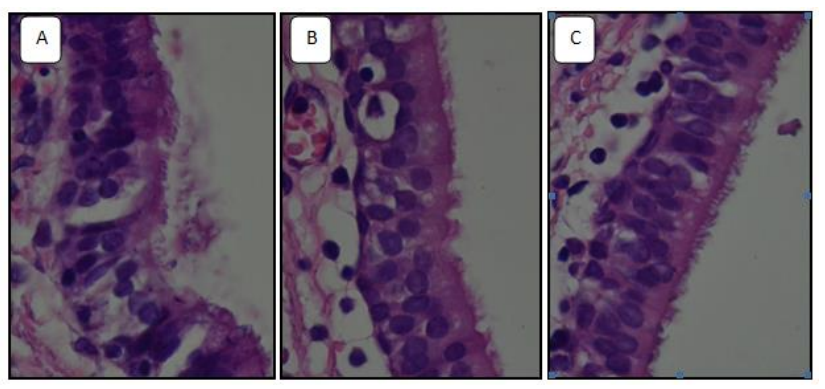

Gambar 1. Gambaran histopatologi trakea pada ketiga kelompok perlakuan, yaitu kelompok kontrol (gambar A), kelompok perlakuan 1 (gambar B) dan kelompok perlakuan 2 (gambar C), (pembesaran 1000x).

\section{Pembahasan}

Studi ini menunjukkan pemberian asap rokok kretek non filter 7 batang per hari pada hewan coba tikus selama 4 minggu dapat meningkatkan rerata jumlah sel goblet yaitu sebesar 23,08 $\pm 11,7$. Rerata jumlah sel goblet pada kelompok yang diberikan asap rokok saja jauh lebih tinggi secara bermakna dibandingkan kelompok perlakuan 1 $(\rho<0.0001)$, namun tidak berbeda bermakna apabila di bandingkan dengan kelompok perlakuan $2(\rho=0,126)$. Walaupun secara statistik didapatkan bahwa tidak ada perbedaan bermakna antara rerata jumlah sel goblet pada kelompok kontrol dengan P2, namun rerata jumlah sel goblet pada kelompok P2 jauh lebih sedikit $(15,32 \pm 4,4)$ dibanding kelompok kontrol $(23,08 \pm 11,7)$ mendekati rerata jumlah sel goblet pada kelompok P1 $(14,44 \pm 14,8)$.

Hasil ini sejalan dengan studi yang dilakukan Takeyama dimana paparan asap rokok 8 batang per hari selama 5 hari pada tikus jantan galur Sprague-Dawley menunjukkan peningkatan jumlah sel goblet dari $40 \quad \pm 19$ menjadi $167 \quad \pm 19 \quad$ sel $/ \mathrm{mm}$ $(\mathrm{p}<0,001) .{ }^{22} \mathrm{Hal}$ ini juga tidak berbeda dengan studi yang dilakukan oleh Arkeman dimana pada pemajanan asap rokok kretek non filter 8 batang per hari dalam waktu 30 menit selama 20 hari pada tikus Sprague-Dawley jantan menunjukkan rata-rata persentase sel goblet pada kelompok kontrol sebesar 20,3 \pm 7,94. Kelompok yang hanya diberikan pemajanan asap rokok rata-rata persentase sel goblet

Ika Dyah Kurniati dan Afiana Rohmani, Ekstrak Buah Kersen (Muntingia calabura) dalam Menurunkan Jumlah Sel Goblet pada Tikus yang Dipapar Asap Rokok 
besarnya $51,2 \pm 17,23$, sedangkan pada kelompok yang diberikan tambahan vitamin $\mathrm{C}$ dan E rata-rata persentase sel goblet masingmasing besarnya $21,4 \pm 4,99$ dan $19,7 \pm 7,27 .^{23}$

Studi ini menunjukkan bahwa pemberian ekstrak buah kersen pada tikus yang dipapar asap rokok mampu mencegah terjadinya peningkatan jumlah sel goblet. Buah kersen mengandung antioksidan antara lain vitamin $\mathrm{C}$, vitamin $\mathrm{E}$, fenol, flavonoid dan antosianin. ${ }^{21}$ Komponen antioksidan seperti asam fenol, polifenil dan flavonoid mampu memangsa radikal bebas dan menghambat mekanisme oksidatif. Pemberian ekstrak methanol buah kersen dosis $200 \mathrm{mg} / \mathrm{kgBB} / \mathrm{hari}$ pada tikus yang diinduksi hepatotoksik mampu meningkatkan kadar antioksidan enzimatis pada jaringan hepar secara signifikan antara lain SOD, CAT dan Glutathione peroxidase (GPx).

Selain itu juga didapatkan penurunan kadar vitamin $\mathrm{E}$ dan $\mathrm{C}$ yang signifikan setelah pemberian ekstrak buah kersen. Hal ini membuktikan bahwa efek hepatoprotektif terjadi karena kemampuan ekstrak buah kersen untuk memblokir bioaktivasi dari toksin dan merupakan antioksidan yang poten dalam menangkap radikal bebas dan menghambat peroksidasi lipid. Vitamin $\mathrm{C}$ dan vitamin $\mathrm{E}$ mampu bertindak sebagai scavenger radikal bebas yang penting yang mampu digunakan sebagai pemutus rantai (chain-breaking antioxidant) di membran. Vitamin $\mathrm{E}$ mengurangi hidroperoksida lipid yang dihasilkan selama proses peroksidasi dan melindungi struktur sel terhadap kerusakan sel. $^{24}$

Kandungan antioksidan lain pada buah kersen yaitu flavonoid, yang memiliki aktivitas antiinflamasi, antialergi, anti-virus, dan antikarsinogenik. Salah satu mekanisme yang dapat digunakan untuk menjelaskan hubungan antara aktivitas anti-inflamasi dan anti-oksidan adalah reaksi yang disebabkan oleh ROS. ROS yang merupakan jenis stimulus inflamasi, yang menyebabkan pelepasan oksida nitrat (NO). Hal tersebut menunjukkan bahwa pemblokiran ROS akan menyebabkan penurunan sintesis NO, yang pada gilirannya akan mengarah pada aktivitas anti-inflamasi, anti kanker dan antioksidan. ${ }^{20}$

Studi ini menunjukkan suplementasi buah kersen pada tikus yang dipapar asap rokok mampu mencegah terjadinya peningkatan jumlah atau hiperplasia sel goblet. Walaupun demikian masih diperlukan studi lebih lanjut mengenai suplementasi buah kersen dengan populasi yang lebih besar untuk menilai peran antioksidan buah kersen terhadap perubahan fungsi paru pada perokok.

\section{Kesimpulan dan Saran}

Pemberian ekstrak buah kersen yang mengandung antioksidan alamiah pada tikus yang terpapar asap rokok dapat menurunkan jumlah sel goblet pada trakea tikus.

\section{Daftar Pustaka}

1. World Health Organization. Global Alliance against Chronic Respiratory Diseases (GARD). General Meeting 
Report; 2008 May 30-31; Istanbul, Turkey. Geneva: WHO; 2008.

2. Global Initiative for Chronic Obstructive Lung Disease [homepage on the Internet. Bethesda: GOLD [cited 2012 Dec 10]. Global Strategy for the Diagnosis, Management and Prevention of PPOK--Revised, 2011. Available from: http://www.goldPPOK.org/

3. de Faria CA, de las Heras Kozma R, Stessuk T, Ribeiro- Paes JT. Experimental basis and new insights for cell therapy in Chronic Obstructive Pulmonary Disease. Stem Cell Rev. 2012; 8(4): 1236-44. http://dx.doi.org/10.1007/ s12015-0129410-7 PMid:23054962

4. Ribeiro-Paes JT, Stessuk T, de las Heras Kozma R. Cell Therapy in Chronic Obstructive Pulmonary Disease: State of the Art and Perspectives. In: Ong KC, editor. Chronic Obstructive Pulmonary Disease - Current Concepts and Practice. Rijeka: InTech; 2012. p. 455-74.

5. Kementerian Kesehatan RI. Penyajian Hasil Pokok- Pokok Riset Kesehatan Dasar Tahun 2013. Jakarta: Badan Penelitian dan Pengembangan Kesehatan Kementerian Kesehatan RI; 2013.

6. Gultom, H.L.2011. Pengaruh Paparan Asap Rokok Terhadap Gambaran Histopatologi Saluran Pernapasan Bagian Konduksi Mencit (Mus musculus L) Jantan Galur DDY.Skripsi Fakultas Kedokteran Universitas Lampung. Bandar Lampung.
7. Junqueira, L.C. \& Carneiro, J.2007.Basic Histology: Text \& Atlas 10th Edition. The McGraw-Hill Companies. New York.

8. Halliwell B and Gutteridge JMC. Antioxidant Defences In Free Radicals. In: Biology and Medicine 3rd edition. New York: Oxford University Press; 1999.

9. Muhammad I. Efek Antioksidan Vitamin C Terhadap Tikus (Rattus norvegicus L) Jantan Akibat Pemaparan Aasap Rokok. Tesis. Bandung. 2009.

10. Diken H, Kelle M, Tomer C, Denuz B, Baylan Y, Permet A. Effects of Cigarrete Smoking on Blood Antioxidant Status in Short-term and Long-term Smokers. Turk J Med Sci. 2001 (31)553-557.

11. Drath DB,Karnovsky ML, Huber GL. Tobacco smoke. Effects on Pulmonary host defense inflammation.USA. 1979; 3(3): 281-8.

12. Rima A, Suradi, Surjanto E dan Yunus F. Korelasi antara jumlah makrofa, neutrofil dan kadar enzim matrix metalloproteinase (MMP)-9 Pada cairan kurasan Bronkial perokok. Surakarta. J Respir Indo. 2007;27 (3)3.

13. Sirianni FE, Chu FSF, Walker DC. Human alveolar wall fibroblasts directly link epithelial type 2 cells to capillary endothelium. Am J Respir Crit Care Med 2003; 168: 1532-1537.

14. Kuebler WM, Parthasarathi K, Wang PM, Bhattacharya J.Anovel signaling mechanism between gas and blood compartments of the lung.J Clin Invest 2000;105:905-913.

Ika Dyah Kurniati dan Afiana Rohmani, Ekstrak Buah Kersen (Muntingia calabura) dalam Menurunkan Jumlah Sel Goblet pada Tikus yang Dipapar Asap Rokok 
15. Ichimura H, Parthasarathi K, Quadri S, Issekutz AC, Bhattacharya J.Mechanooxidative coupling by mitochondria induces proinflammatory responses in lung venular capillaries. J Clin Invest 2003; 111: 691-699.

16. Mudjiwijono Handaru E1, Nunuk Sri M2, Indah Srini Nk3 Pemberian Jus Tomat (Lycopersicum esculentum) Per Oral Dapat Menurunkan Jumlah Sel Epitel Bronkhus Utama Tikus Putih yang Dipapar Asap Rokok Sub Kronik. Jurnal Kedokteran Brawijaya, Vol. 26, No. 1, Februari 2010. 32-26.

17. Crystal, RG. 1991. Biologi of Free Radicals, Introduction. Am J Med, 91: 15.

18. Noguci N and Niki E., 1999. Chemistry of Active Oxygen Species and Antioxidationts in Antioxidant Status, diet, Nutrition, nad Health. Edited by Papas AM. CRC Press. New York. p. 3-37.

19. Miguel MG. Antioxidant Activity of Medicinal and Aromatic Plants. A Review. Flavour and Fragrance Journal. 2010; 25(5): 291-312.

20. Preethi K, Premasudha P, Keerthana K. Anti-inflammatory Activity of Muntingia calabura Fruits. Pharmacognosy Journal, Volume 4, Issue 30, July-August 2012, Pages 51-56.

21. Gomathi R, Anusuya N and Manian S. A Dietary Antioxidant Supplementation of Jamaican Cherries (Muntingia Calabura L) Attenuates Inflammatory Related Disorders. Food Sci.Biotechnol. (2013);22(3): 787-794.

22. Takeyama K, Jung B, Shim JJ, Burgel PR, Dao-Pick T, Ueki F, et al. Activation of epidermal growth factor receptors is responsible for mucin synthesis induced by cigarette smoke. Am J Physiol Lung Cell Mol Physiol 2001; 280: L165-L72.

23. Arkeman H, David. Efek vitamin C dan E terhadap sel goblet saluran nafas pada tikus akibat pajanan asap rokok. Universa Medicina, April - Juni 2006, Vol. 25 No. 2. 61-66.

24. Preethi K, Sasikumar JM. and Microcore. hepatoprotective effect of muntingia calabura fruit extracts against paracetamol induced oxidative stress in wistar albino rats. International Journal of Biotechnology and Bioengineering Research. 2010; 2 (1):21-7. 